\title{
Social Media Analytics: Instagram Utilization for Delivering Health Education Messages to Young Adult in Indonesia
}

\author{
Odilia Firsti Wida Mukti ${ }^{1}$, Nuzulul Kusuma Putri ${ }^{1,2)}$ \\ ${ }^{1}$ Department of Health Policy and Administration, Faculty of Public Health, Universitas Airlangga, \\ Surabaya, Indonesia \\ 2 The Airlangga Centre for Health Policy, Surabaya, Indonesia \\ Corresponding directed to e-mail: nuzululkusuma@fkm.unair.ac.id
}

\begin{abstract}
Background: Social media marketing has become one of the most widely used forms of digital marketing in social marketing. Organizations that drive change in young people, such as the Center for Indonesia's Strategic Development Initiatives (CISDI), rely heavily on social media marketing in communicating various health issues to the public. However, only a few studies have used social media related data to understand the effectiveness of this media in the delivery of health issues. Objective: This study aims to analyze the utilization of social media marketing conducted by CISDI for delivering health messages and its impact to young adult in Indonesia using social media analytics. Method: Realtime data were obtained through Keyhole as a social media analytics tool and audience insight of online and offline classes used for social analytic in this study. This research monitored the use of CISDI's social media by using audience metrics and individual post metrics collected from April 2019 to April 2020. Online and offline class audience data were obtained from the CISDI engagement database which was used as a complement to audience metrics information. Analysis of metrics was used to describe the audience that had been reached by the Center for Indonesia's Strategic Development Initiatives, how health messages could engage with the groups of audience, and how social media marketing can move the audience. Results: The result of this study shows that social media utilization for delivering health messages brought impact on audience participation. Current issues such as sex education have an average involvement rate of $14.43 \%$. By promoting through social media, CISDI has engaged 10,266 audience to participate in their classes. Conclusion: Social media utilization benefit CISDI in engaging audience and move them to participate in their cause.
\end{abstract}

Keyword: Health Communication, Social Analytics, Social Media Marketing.

\section{INTRODUCTION}

The development of technology has brought improvement in our life. We can access everything through the internet. Thus, our relationship with the internet has become inseparable. According to the study done by Polling Indonesia and Indonesian Internet Service Operator Association (APJII) in 2019, there are 117.21 million internet users in Indonesia. The number has increased by $10.12 \%$ from 2018. From the same source, it is stated that the internet has been used daily by around $64.8 \%$ of the population in Indonesia. (APJII, 2019)

Most internet users access information through social media. Social media is the new effective communication tool. The main user of social media are young adults (Alhabash and $\mathrm{Ma}, 2017)$. Therefore, it is best to use social media as promoting tool to young adults. Instagram is one of the most popular social media used by people globally. (Vinaika and Manik, 2017). This encourages businesses to use Instagram as marketing promotion media. (Turancl, 2019). Social media is used as the new health promoting media due to its effectiveness in spreading information. (Obregon and Waisbord, 2012; Wright, Sparks and O'Hair, 2012; Househ, 2014; Wymer, 2015; Ahmed and Bates, 2016; Marinescu and Mitu, 2016; Syed-Abdul, Gabarron and Lau, 2016; Sekalala and Niezgoda, 2018; Bian et al., 2019). There is also a shift in health marketing as healthcare and health organizations also 
implement social media marketing. ((Radu et al., 2017).

The utilization of social media for delivering health messages also face several challenges. There are lot of information posted in social media, therefore the information can be overloaded. Despite the abundant amount of post, it is hard to find reliable resource information in social media as everyone can freely share their thoughts on social media. (Naseri Boori Abadi and Sheikhtaheri, 2015). It should be noted that young people are more attracted to a post with photo with words than the words alone. (Alhabash and Ma, 2017). Therefore, it is necessary for credible public health organization to convey indepth health promoting messages in interactive way to engage their audience.

In order to fulfill the need of health information among young adult in Indonesia, Center for Indonesia's Strategic Development Initiatives (CISDI) delivers robust and interactive health messages on Instagram. As the urgency of health information dissemination arise during the coronavirus (COVID-19) pandemic, CISDI increase their posting frequency. The shift is made for the sake of engaging more audience.

It is essential for CISDI to measure and evaluate their performance on social media. Social media is the face of the brand. Its implementation benefit the business to gain awareness and reach more potential customers. (Pourkhani et al., 2019). Therefore, organizations need to take social media accounts seriously. It is important to monitor their performance through social media platforms. Social media analytics (SMA) is done by collecting, monitoring, analyzing, summarizing, and visualizing social media data through specific algorithm to conduct research for several purposes. (Andryani, Negara and Triadi, 2019). This analysis can gather information on trends, current issues, and other kind of information. (Stieglitz et al., 2018).

SMA is very beneficial for organizations as it can be used for measuring organizations' performance, whether they attract the right target of audience and improve their sales or their promotion through social media does not give anything in return. This means, frequent use of SMA will help an organization to understand what they can do to grow as a brand and expand the range of audience.

Many non-profit organizations use social media as a platform to increase their brand awareness as it contributes to attract more sponsors and raise more funds. The utilization of social media benefits non-profit organizations in improving the involvement and engagement, transparency and accountability, organizational image, and operational. (Lauro, Tursunbayeva and Antonelli, 2019). The benefits are categorized into non-financial benefit and financial benefit. Strategic utilization of social media channels can produce a variety of nonfinancial benefits for NonProfit Organization (NPO), which include access to a global audience, increases in productivity of managers and professionals, provision of continuous feedback channels, and increased web presence. The financial benefits of social media include utilization costs, time savings, fundraising opportunities, and visibility of support.

It is important to non-profit organizations to monitor their impact on society through the social media platform, whether they are influencing enough for people to be aware of the issues they bring or not. By analyzing the metrics of SMA, non-profit organizations can understand the demography of their audience, the reaction to their posts, the type of post their audience likes, and to calculate the number of people they reached and engaged through social media platforms. (Appleby, 2016). SMA helps non-profit organizations to evaluate their current marketing strategy and how to improve them. It will enable non-profit organizations to build an audience-based marketing strategy. Thus, they can generate intriguing content for promoting their good cause.

Research on SMA has been rapidly conducted in the past few years. However, not many studies on the effectiveness of social media in delivering health issues have been found. Previous study only portrayed the implementation of social media in delivering health issues and the exposure to health information but not their impact to the audience. (Dunlop, Freeman and Jones, 2016; Kamel Boulos, Giustini and Wheeler, 2016; Habibi, Farpour and Pirzad, 2017; Roberts, Callahan and O'Leary, 2017; 
Khatimah and Laksmi, 2019; Rummo et al., 2020). This study aims to analyze the impact of communication on health issues through social media marketing conducted by CISDI using social media analytics.

\section{METHOD}

This research was a social media analytics research that use secondary data from real-time social media analytics data which had been collected by CISDI through Keyhole analytics as social media analytics tool. Keyhole is a social media analytics tool that provides in-depth data analysis of all social media metrics.

This study monitored the use of the CISDI Instagram account by using audience metrics and individual post metrics collected from April 2019 to April 2020. The sample used in this study was 162 posts on CISDI's Instagram account which delivered health messages related to Sustainable Development Goals' (SDGs). Online class audience data was collected from the CISDI engagement database and used as supplementary information for audience metrics.

The analysis was divided into three main parts of marketing strategy, namely. segmenting, targeting, and positioning. The data of audience characteristics was crawled through followers' insight of the CISDI's Instagram account. Then it was grouped based on their socio demography characteristics. Analysis of audience metrics was used to describe the audience that the CISDI had reached. Positioning was the process of deciding the position a brand wants to occupy their target needs. The positioning strategy was analyzed based on various health programs CISDI has promoted through their Instagram account.

As CISDI's interest is on achieving Sustainable Development Goals (SDGs), the health messages were grouped according to SDGs. Lastly, the engagement of designed health messages to the audience was evaluated by observing the individual post metrics to understand how effective social media marketing could move the audience into the CISDI program. The impact of social media utilization was measured by comparing the number of participants of
CISDI's classes before and after using online platform.

\section{RESULTS AND DISCUSSION}

\section{Segmenting}

CISDI used socio demography characteristics of their audience in segmenting. They segmented their audience into youth which consist of adolescence and young adults. People in such age groups mostly spend their time on social media due to their curiosity and interest in communication tool.(CarcellerMaicas, 2016). Instagram is the most popular social media used by young adults. (Huang and Su, 2018). Therefore, they choose Instagram as the communication and marketing tool.

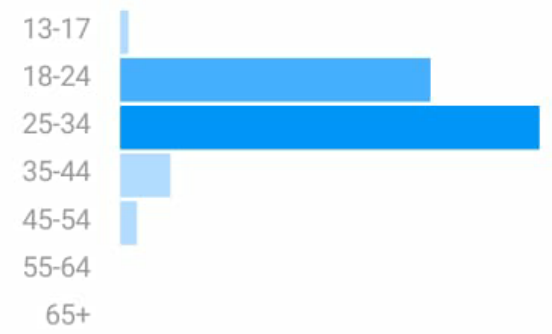

Source: CISDI's Instagram's followers' insights

Figure 1. Characteristics of Audience Based on Age

Based on Figure 1, it is shown that the majority of the audiences are 25-34 years old, followed by audiences between 18-24 years old. Unfortunately, the frequency nor the percentage of each group of age cannot be seen as the data we obtained only presented the graphic of the said characteristics in Figure 1. It is presented that the audiences of CISDI's Instagram account are young adults.

Table 1. Characteristics of Audience Based on Sex

\begin{tabular}{lrr}
\hline \multicolumn{1}{c}{ Sex } & Frequency & Percentage (\%) \\
\hline Male & 2186 & 31 \\
Female & 4865 & 69 \\
\hline Total & 7051 & 100 \\
\hline
\end{tabular}

Based on Table 1, 4865 followers or $69 \%$ of the audiences are female. From the description above, it can be concluded that the majority of CISDI's Instagram account's audiences are female young adults.

Segmentation is the primary step of marketing strategy. This is the actual process of dividing a range of customer 
into several sub-groups (Ivanova, 2019). The concept of market segmentation is segmenting the customers into distinctive subgroups based on defined characteristics. Referred to the result of analysis above, the CISDI's market segmentation and their audiences on Instagram are aligned.

\section{Targeting}

After the market has been segmented, the company then select their needs, so that they can choose the most profitable segments to be served (Ivanova, 2019). After segmenting the audience into several subgroups, CISDI chose a specific subgroup as their target. As a civil society organization, CISDI aims to ensure equality in health which stated on their vision. Therefore, they chose youth whose concern in health issues as their marketing target.

\section{Positioning}

Positioning is the final stage of basic strategy in marketing. The company needs to show their distinctive feature and authenticity from their competitors, so that consumers will consider their products and or services over other brands. (Ivanova, 2019).

CISDI positioned themselves as civil society the organization working on health issue. Social media has been used for public health communication tool. (Scriven, 2017; Kim and Song, 2020; Stellefson et al., 2020). Therefore, they raise awareness through social media. The positioning strategy in this study is analyzed by observing the content of health messages CISDI delivered through their Instagram account.

As seen on Table 2, SDGs is used as indicators for grouping the health messages delivered by CISDI through their Instagram account. CISDI promoted four health related goals from SDGs-zero hunger, good health and well-being, gender equality, clean water and sanitation.

According to their Instagram post, they often brought topics on good health and well-being containing healthcare and communicable disease messages. The average engagement rate of those topics is $8.15 \%$ and $7.93 \%$ consecutively. Contrary to the most communicated issues on their Instagram, the most engaging post was about sex education which average engagement rate reached $14.43 \%$. Meanwhile, their lowest average engagement rate is $4.77 \%$ on posts about sustainable gastronomy for food availability and food security.

From the result, it can be seen that the audiences are more interested in topics about sex education as it hit the highest average engagement rate. Sex education are the topics that are frequently brought into discussion these 
days. People are curious to dig in more information on those topics. CISDI delivered the messages that have not been brought by other organizations. The innovation and authenticity drive the audiences to interact with CISDI and other audience in the said post to share their knowledge on the topics. However, the messages were not the only contributor to the engagement rate. When and how the messages were delivered also contribute to determine the engagement rate. It is important to display visually pleasing design to convey the messages. 
40 Jurnal Promkes: The Indonesian Journal of Health Promotion and Health Education Vol. 9 No. 1, March 2021, 35-43 doi: 10.20473/jpk.V9.11.2021.35-43

Table 2. Health Promoting Messages Delivered on Social Media

\begin{tabular}{|c|c|c|}
\hline SDGs Goals & Messages content & $\begin{array}{c}\text { Average } \\
\text { Engagement } \\
\text { Rate }\end{array}$ \\
\hline \multicolumn{3}{|l|}{ Goal 2: Zero Hunger } \\
\hline \multirow[t]{8}{*}{ Nutrition } & The importance of breastfeeding for infant & $8.16 \%$ \\
\hline & Breastfeeding regulations & $11.32 \%$ \\
\hline & $\begin{array}{l}\text { Government's role in increasing breastfeeding rate in } \\
\text { Indonesia }\end{array}$ & $6.96 \%$ \\
\hline & Youth involvement in breastfeeding awareness & $8.59 \%$ \\
\hline & Key factors of optimizing breastfeeding rate & $7.17 \%$ \\
\hline & $\begin{array}{l}\text { Research publication in strengthening nutrition } \\
\text { through primary healthcare }\end{array}$ & $10.03 \%$ \\
\hline & $\begin{array}{l}\text { The difference between nutritional problem on } \\
\text { children and adult }\end{array}$ & $9.47 \%$ \\
\hline & Breastfeeding during pandemics & $7.25 \%$ \\
\hline $\begin{array}{l}\text { Food availability and } \\
\text { food security }\end{array}$ & Sustainable gastronomy & $4.77 \%$ \\
\hline \multicolumn{3}{|c|}{ Goal 3: Good health and well-being } \\
\hline \multirow[t]{4}{*}{ Healthcare } & The importance of primary healthcare & $9.80 \%$ \\
\hline & Discussion on health data digitalization & $8.26 \%$ \\
\hline & $\begin{array}{l}\text { CISDI's Health Outlook: A comprehensive study on } \\
\text { health development }\end{array}$ & $8.22 \%$ \\
\hline & The roles of primary healthcare during pandemic & $6.32 \%$ \\
\hline $\begin{array}{l}\text { Universal } \\
\text { Coverage }\end{array}$ & $\begin{array}{l}\text { Strengthening government commitment to reduce the } \\
\text { burden on universal health coverage }\end{array}$ & $6.84 \%$ \\
\hline \multirow[t]{2}{*}{ Narcotics } & Tobacco control & $6.69 \%$ \\
\hline & Discussion on cigarette smoke & $8.05 \%$ \\
\hline \multirow{12}{*}{$\begin{array}{l}\text { Non-communicable } \\
\text { disease } \\
\text { Communicable disease }\end{array}$} & Mental health & $7.36 \%$ \\
\hline & Cancer on reproduction system & $7.56 \%$ \\
\hline & Diabetes prevention & $7.97 \%$ \\
\hline & Immunization & $7.62 \%$ \\
\hline & Malaria awareness & $5.47 \%$ \\
\hline & Introduction to hypertension & $5.14 \%$ \\
\hline & Tuberculosis prevention and elimination & $9.76 \%$ \\
\hline & Health surveillance for battling against COVID-19 & $9.65 \%$ \\
\hline & Strategy for handling COVID-19 case in Indonesia & $8.65 \%$ \\
\hline & COVID-19 prevention & $10.27 \%$ \\
\hline & Government's action in reducing COVID-19 infection & $7.07 \%$ \\
\hline & Education on personal protective equipment (PPE) & $7.70 \%$ \\
\hline \multicolumn{3}{|l|}{ Goal 5: Gender equality } \\
\hline \multirow{3}{*}{$\begin{array}{l}\text { Gender mainstreaming } \\
\text { in health } \\
\text { Contraception }\end{array}$} & Reinforcing factors of gender mainstreaming & $7.76 \%$ \\
\hline & The development of gender equality in Indonesia & $4.89 \%$ \\
\hline & $\begin{array}{l}\text { Health related issue in Indonesia Criminal Code Bill } \\
\text { (RKUHP) }\end{array}$ & $5.69 \%$ \\
\hline \multirow[t]{2}{*}{ Sex education } & Health reproduction program for youth in Indonesia & $14.43 \%$ \\
\hline & The importance of sex education & $14.34 \%$ \\
\hline \multicolumn{3}{|c|}{ Goal 6: Clean water and sanitation } \\
\hline Sanitation & Waste management during pandemic & $7.46 \%$ \\
\hline
\end{tabular}


Table 3. The Number of Participants in Classes Conducted by CISDI

\begin{tabular}{lr}
\hline \multicolumn{1}{c}{ Category } & \multicolumn{1}{c}{ Frequency } \\
\hline Online Class & 267 \\
\hline Diskusi Digital Kaum Muda & 8457 \\
Kelas Online Series & 473 \\
RuangTemu.Online & 50 \\
RuangTemu.Tematik & 45 \\
RuangTemu.Spesial & 7 \\
SDGs Jakarta Banget & 245 \\
Webinar Hari Bumi & 682 \\
Webinar Terumbu Karang & 10226 \\
\hline Total & 240 \\
\hline Offline Class & 188 \\
\hline YTH TB & $\mathbf{4 2 8}$ \\
Lokapala & 10648 \\
\hline Total & \\
\hline Total Participants &
\end{tabular}

As seen on Table 3, CISDI has engaged 10648 participants. The use of social media gives impact on audience participation. Before using online platform for conducting classes, there were only 428 people that participate in CISDI's offline classes (YTH TB and Lokapala). The number of participants increased as CISDI shift their method. CISDI has engaged 10226 people to participate in their online classes. The audience are more likely to participate in online classes as it is accessible for audience who lives remotely from CISDI's location. Social media utilization benefited health organization to be engaged with more people. Thus, this effectively bring impact in raising awareness on health issues to more people.

\section{CONCLUSION}

Social media has been used not only for personal purpose but also for business and organizations. Civil society organizations promote their cause through social media to raise awareness and engage audience. CISDI positioned themselves as civil society organization focusing on health issues. They targeted youth and young adults who have concern in health issues. In order to reach their audience, they use Instagram as platform to deliver health messages. From the social analytics result, their audience are more likely to be engaged to issues that currently trending, such as sex education. CISDI has succeed to move their audience to participate in their classes to discuss health issues.
Ahmed, R. and Bates, B. R. (2016) 'Health communication and mass media: An integrated approach to policy and practice', Health Communication and Mass Media: An Integrated Approach to Policy and Practice, pp. 1-244. doi: 10.4324/9781315586335.

Alhabash, S. and Ma, M. (2017) 'A Tale of Four Platforms: Motivations and Uses of Facebook, Twitter, Instagram, and Snapchat Among College Students?', Social Media and Society, 3(1). doi: $10.1177 / 2056305117691544$.

Andryani, R., Negara, E. S. and Triadi, D. (2019) 'Social Media Analytics: Data Utilization of Social Media for Research', Journal of Information Systems and Informatics, 1(2), pp. 193-205. doi: 10.33557s/journalisi.v1i2.23.

APJII (2019) 'Penetrasi \& Profil Perilaku Pengguna Internet Indonesia Tahun 2018', Apjii, p. 51. Available at: www.apjii.or.id.

Appleby, M. (2016) 'Nonprofit Organizations and the Utilization of Social Media: Maximizing and Measuring Return of Investment', 12(1), pp. 4-26.

Bian, J. et al. (2019) Social Web and Health Research: Benefits, Limitations, and Best Practices. Cham, Switzerland: Springer International Publishing. Available at: https: / / books.google.co.id/books?id=9 6WfDWAAQBAJ.

Carceller-Maicas, N. (2016) 'Youth, health and social networks: Instagram as a research tool for health communication', Metode, 6(6), pp. 227-233. doi: 10.7203/metode.6.6555.

Dunlop, S., Freeman, B. and Jones, S. C. (2016) 'Marketing to youth in the digital age: The promotion of unhealthy products and health promoting behaviours on social media', Media and Communication, 4(3), pp. 35-49. doi: 10.17645/mac.v4i3.522.

Habibi, L., Farpour, H. R. and Pirzad, R. (2017)

'SosMed_Health_Comm10.5923.j.ijbcs. 20170604.03.pdf', 6(4), pp. 74-79. doi: 10.5923/j.ijbcs.20170604.03.

Househ, M. (2014) Social Media and Mobile Technologies for Healthcare. Hershey PA, USA: IGI Global (Advances in Healthcare Information Systems and 
Administration (2328-1243)). Available at:

https: / /books.google.co.id/books?id=Q p1_BAAAQBAJ.

Huang, Y. T. and Su, S. F. (2018) 'Motives for instagram use and topics of interest among young adults', Future Internet, 10(8). doi: $10.3390 /$ fi10080077.

Ivanova, M. (2019) Travel Marketing, Tourism Economics and the Airline Product. An Introduction to Theory and Practice, Journal of Revenue and Pricing Management. doi: 10.1057/s41272-018-00173-3.

Kamel Boulos, M. N., Giustini, D. M. and Wheeler, S. (2016) 'Instagram and WhatsApp in health and healthcare: An overview', Future Internet, 8(3). doi: 10.3390/fi8030037.

Khatimah, K. and Laksmi, L. (2019) 'Prevent Stunting Campaign: Dissemination of Health Information through Instagram', Record and Library Journal, 5(1), p. 80. doi: 10.20473/rlj.v5-i1.2019.80-89.

Kim, J. and Song, H. (2020) 'Technology and Health: Promoting Attitude and Behavior Change'. Oxford, UK: Academic Press. Available at: http://repositorio.unan.edu.ni/2986/1 /5624.pdf.

Lauro, S. Di, Tursunbayeva, A. and Antonelli, G. (2019) 'How Nonprofit Organizations Use Social Media for Fundraising: A Systematic Literature Review', 14(7), pp. 1-22. doi: 10.5539/ijbm.v14n7p1.

Marinescu, V. and Mitu, B. (2016) The Power of the Media in Health Communication. New York: Taylor \& Francis. Available at: https://books.google.co.id/books?id=s xwFDAAAQBAJ.

Naseri Boori Abadi, T. and Sheikhtaheri, A. (2015) 'Social media and health care: Necessity of facing their challenges', Iranian Journal of Public Health, 44(4), pp. 596-597.

Obregon, R. and Waisbord, S. (2012) The Handbook of Global Health Communication. New York: Wiley Blackwell (Handbooks in Communication and Media). Available at:

https: / / books.google.co.id/books?id=0 XkSiUBop48C.

Pourkhani, A. et al. (2019) 'The impact of social media in business growth and performance: A scientometrics analysis', International Journal of Data and Network Science, 3(3), pp. 223-244. doi: 10.5267/j.ijdns.2019.2.003.

Radu, G. et al. (2017) 'The adaptation of health care marketing to the digital era.', Journal of medicine and life, 10(1), pp. 44-46. Available at: http://www.ncbi.nlm.nih.gov/pubmed /28255375\%0Ahttp://www.pubmedcen tral.nih.gov/articlerender.fcgi?artid=P MC5304370.

Roberts, M., Callahan, L. and O'Leary, C. (2017) 'Social media: A path to health literacy', Information Services and Use, 37(2), pp. 177-187. doi: $10.3233 /$ ISU-170836.

Rummo, P. E. et al. (2020) 'Examining the relationship between youth-targeted food marketing expenditures and the demographics of social media followers', International Journal of Environmental Research and Public Health, 17(5). doi: 10.3390/ijerph17051631.

Scriven, A. (2017) Promoting Health: A Practical Guide - E-Book: Ewles \& Simnett. Elsevier Health Sciences. Available at: https://books.google.co.id/books?id=f JwqDWAAQBAJ.

Sekalala, S. and Niezgoda, B. C. (2018) Global Perspectives on Health Communication in the Age of Social Media. Hershey PA, USA: IGI Global (Advances in Healthcare Information Systems and Administration (23281243)). Available at: https://books.google.co.id/books?id=j elIDWAAQBAJ.

Stellefson, M. et al. (2020) Exploring the Role of Social Media in Health Promotion. Basel, Switzerland: MDPI. Available at: https://books.google.co.id/books?id=X R_sDWAAQBAJ.

Stieglitz, S. et al. (2018) 'Social media analytics - Challenges in topic discovery, data collection, and data preparation', International Journal of Information Management. Elsevier, 39(December 2017), pp. 156-168. doi: 10.1016/j.ijinfomgt.2017.12.002.

Syed-Abdul, S., Gabarron, E. and Lau, A. Y. S. (2016) Participatory Health through Social Media, Participatory Health through Social Media. doi: 10.1016/C2015-0-05709-4.

Turancı, E. (2019) 'The Use of Instagram 
as a Public Relations Tool in Health Tourism: An Analysis on "Health Tourism Turkey” Hashtag', International Journal of Health Management and Tourism, 4(1), pp. 44-60. doi: 10.31201/ijhmt.521852.

Vinaika, R. and Manik, D. (2017) 'How Instagram is Changing the Way Marketing Works?', International Journal of Management \& Business Studies, 7(4), pp. 12-16. Available at: http: / /www.ijmbs.com/Vol7/issue4/2- raj-vinaika.pdf.

Wright, K. B., Sparks, L. and O'Hair, H. D. (2012) Health Communication in the 21st Century. New York: Wiley Blackwell. Available at: https: / / books.google.co.id/books?id=i At6qnSOHpOC.

Wymer, W. (2015) Innovations in Social Marketing and Public Health Communication, Springer. doi: 10.2108/zsj.23.843. 